\title{
A Rare Case Report: Dirofilariasis and B-cell Lymphoma in Cervical Lymph Nodes
}

Рядък случай от клиничната практика: шийна дирофилариоза и В-клетъчен лимфом

\author{
Dzhambazov K., Stefan S. Konsulov, Rakadzieva M., S. Konsulov \\ ENT department, UMHAT "St. George" - Plovdiv \\ Medical University of Plovdiv, Faculty of Medicine
}

\author{
К. Джамбазов, Стефан С. Консулов, М. Ракаджиева, С. Консулов \\ Клиника по Ушни, носни и гърлени болести, УМБАЛ „Св. Георги“ЕАД -Пловдив \\ Катедра по УНГ болести, Медицински факултет, МУ - Пловдив
}

\section{Introduction}

Dirofilariasis is a transmissible helminthiasis caused by parasites of the genus Dirofilaria Dirofilaria repens and Dirofilaria immitis. The source of infection are non-dewormed dogs and cats, and the vectors are mosquitoes of the genus Aedes or Anopheles. Subcutaneous (at the site of the bite) or haematogenous invasion is typical, and in very rare cases - lymphogenic too (when a single larva reaches sexual maturity in a peripheral lymph node). In the period 1973-2011 in Bulgaria, a total of 47 cases of dirofilariasis have been registered in humans, with about $20 \%$ of cases being ocular dirofilariasis, about 9\% pulmonary, and in other cases the localization is subcutaneous in different parts of the body. In the period 2000-2011 in Europe, statistics show 21 registered cases of pulmonary dirofilariasis and 940 of subcutaneous one. According to our data, only 5 cases of dirofilariasis in the cervical lymph nodes have been described worldwide - 1 in Israel, 1 in India, 1 in Hong Kong and 2 in France. Its comorbidity with diffuse B-cell lymphoma with the same localization makes the presented case unique.

\section{Clinical case}

A 77-year-old patient was admitted to the clinic with a complaint of a painless formation on the left neck that gradually got enlarged within a month.

\section{Въведение}

Дирофилариозата е трансмисивна хелминтоза, причинена от паразити от род Dirofilaria Dirofilaria repens и Dirofilaria immitis. Източник на инфекцията са необезпаразитени кучета и котки, а вектори са комари от род Aedes или Anopheles. Характерна е подкожната (на мястото на ухапване) или хематогенната инвазия, като в много редки случаи е възможна и лимфогенна такава (когато единична ларва достигне полова зрялост в периферен лимфнодул).В периода 1973-2011г. в България са регистрирани общо 47 случая на дирофилариоза при хора, като около $20 \%$ от случаите са на окуларна дирофилариоза, около 9\% - на белодробна, а в останалите случаи локализацията е подкожна в различни части на тялото. В периода 2000-2011г. в Европа статистиката показва 21 регистрирани случаи на белодробна дирофилариоза и 940 на субкутанна такава. По наши данни в световен мащаб са описани едва 5 случая на дирофилариоза в шийни лимфни възли - 1 в Израел, 1 в Индия, 1 Хонконг и 2 във Франция. Коморбидността ѝ с дифузен $\mathrm{B}$-едроклетъчен лимфом със същата локализация прави представения случай казуистичен.

\section{Клиничен случай}

77-годишна пациентка бе хоспитализирана в клиниката с оплакване от постепенно нараснала в рамките на един месец неболезнена формация 
At levels I, II and III on the left side of the neck, a formation about $5 \mathrm{~cm}$ diameter, with a firm-elastic consistency and low mobility was found. CT scan of the neck visualized a capsule-free circular lesion in the left submandibular region, between the vascular bundle and the medial contour of the left SCM, measuring $28 / 41 \mathrm{~mm}$, with a density equivalent to a liquid, pushing the enlargedsubmandibular gland aside. (Figure 1.) отляво на шията. От локалния статус на ниво I, II и III отляво на шията се установи формация с големина около 5 см, с твърдо-еластична консистенция и слаба подвижност. Компютьрно томографското сканиране на шията визуализира безкапсулна кръгловата лезия в лява субмандибуларна област, между съдовия сноп и медиалния контур на левия СКМ, с размери 28/41 мм, с пльтност, еквивалентна на течна, избутваща лява субмандибуларна жлеза, която е с уголемени размери. (Фигура 1.)

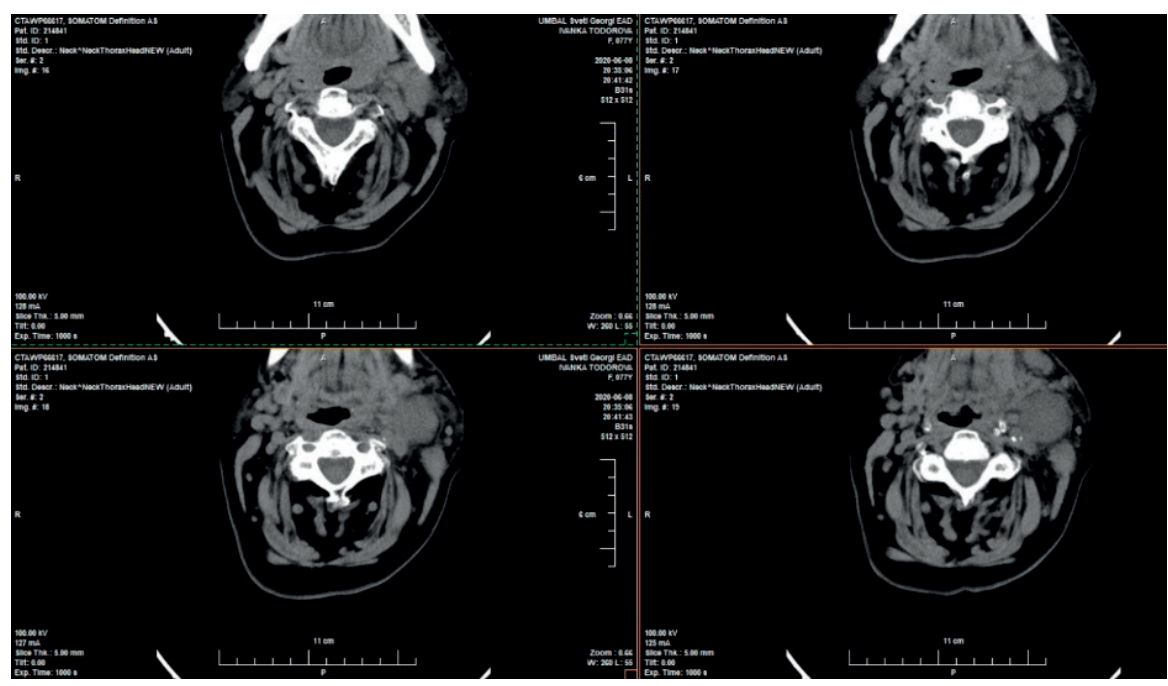

Figure 1.

Фигура 1.

Surgical treatment was performed - selective cervical dissection and extirpation of the left submandibular gland. Histologically, cystic material represented by lymph nodes with central necrosis and detritus was examined. We came across a single cross-cut roundworm, as well as suspected follicular lymphoma abnormalities which were not immunohistochemically supported. After a parasitological consultation, antitoxocara antibodies were tested by ELISA. The result was positive $2.3 \mathrm{U} / \mathrm{ml}$ (ref. 0.9-1.1 U / ml). The diagnosis we made was toxocariasis. Postoperatively, the patient received 10 days of oral therapy with albendazole (Zentel) $800 \mathrm{mg} /$ per day.

Two months after the surgery, the patient was admitted to the hospital, this time with a formation in the left parotid area, with a firm consistency fused with the surrounding tissues. CT of the brain, neck, chest, abdomen was performed - in the left cervical region a lesion measuring 4,7x3,6x4 cm was found, with infiltrative growth involving the lower end of the left parotid gland, anterior half
Проведе се оперативно лечение - селективна шийна дисекция и екстирпация на лява субмандибуларна жлеза. Хистологично се изследва кистичен материал, представен от лимфни възли с централна некроза и детрит. Попадна се на единичен напречно прерязан крьгъл червей, както и на суспектни за фоликуларен лимфом отклонения, които не се подкрепиха имунохистохимично. След консултация с паразитолог се изследваха антитоксокарни антитела чрез метода на ELISA. Резултатьт бе положителен - 2,3 $\mathrm{U} / \mathrm{ml}$ (реф. 0,9-1,1 U/ml). Поставената диагноза бе токсокароза. Следоперативно пациентката проведе 10 дни перорална терапия с албендазол (Zentel) $800 \mathrm{mg}$ дн.

Два месеца след оперативната интервенция пациентката отното постъпи в болничното заведение, този път с формация в лява паротидна област, с твърда консистенция, сраснала с околните тъкани. Осъществи се компютьрно томографско изследване на главен мозък, шия, гръден кош, абдомен - в лява шийна област се установи лезия с размер 4,7х3,6x4 см, с инфил- 
of the left SCM and surrounding the left carotid arteries and the internal jugular vein. (Figure 2.) Mild mediastinal, axillary and abdominal lymphadenopathy was presented. MRI of the brain and cervical region was performed - with data for a volumetric malignant formation originating from the distal portion and the tail of the left parotid gland with signs of decay. тративен растеж, ангажираща долния край на лява паротидна жлеза, предната половина на левия SCM и обграждаща левите каротидни артерии и вътрешната югуларна вена. (Фигура 2.) Наличие на лекостепенна медиастинална, аксиларна и абдоминална лимфаденопатия.

Осъществи се МРТ на главен мозък и шийна област - с данни за обемна малигнена формация, изхождаща от дисталната порция и опашката на лявата паротидна жлеза с белези на разпад.

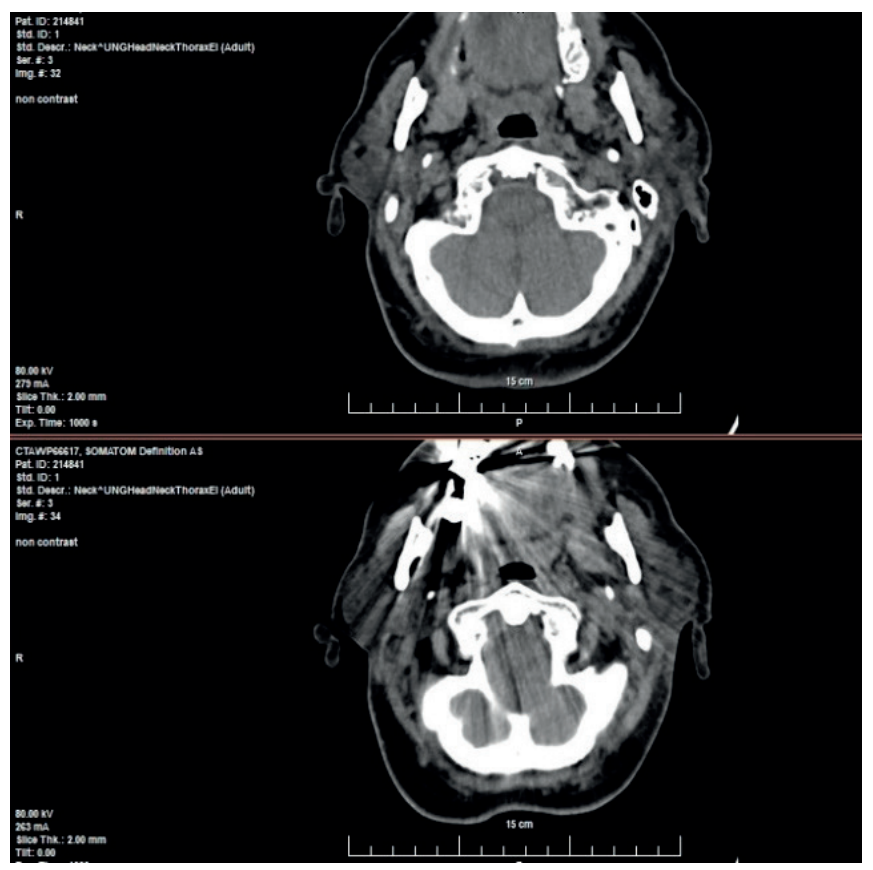

Figure 2.

Фигура 2.

\section{Discussion}

We questioned the initial diagnosis toxocariasis. To our data there isn't any clinical case of cervical lymphadenopathy or sialoadenitis of the submandibular gland due to this parasitic disease. Eosinophilia is a pathognomonic sign of toxocariasis, but it was absent in our case. Anti-toxocara antibodies had a low titer - it turned out that about $19 \%$ of the world's population is seropositive for toxocariasis, and that serological tests for parasites give cross-reactions. Moreover, there was no effect of treatment with albendazole, which is effective in microlarvae, but not in adult forms of parasites. We decided to revise the microscope slide. The result was similar to Toxocara canis nematode, but in fact it turned out to be the adult form of Dirofilaria repens. (Figure 3.)

\section{Обсъждане}

Подложихме на съмнение първоначално поставената диагноза токсокароза. В световната литература не попаднахме на клиничен случай на шийна лимфаденопатия или сиалоаденит на субмандибуларна жлеза, дължащи се на това паразитно заболяване. Еозинофилията е патогномичен белег на токсокарозата, но такава липсваше в случая с нашата пациентка. Антитоксокарните антитела бяха с нисък титър оказа се, че около 19\% от световното население е серопозитивно за токсокароза, както и че серологичните изследвания за паразити дават кръстосани реакции. Още повече - липсваше ефект от лечението с албендазол, който е ефективен при микроларви, но не и при възрастни форми на паразити. Взе се решение микроскопският препарат да бъде ревизиран. Резултатът бе сходен на Тохосаra canis нематод, но всъщност се оказа възрастната форма на Dirofilaria repens. (Фигура 3.) 


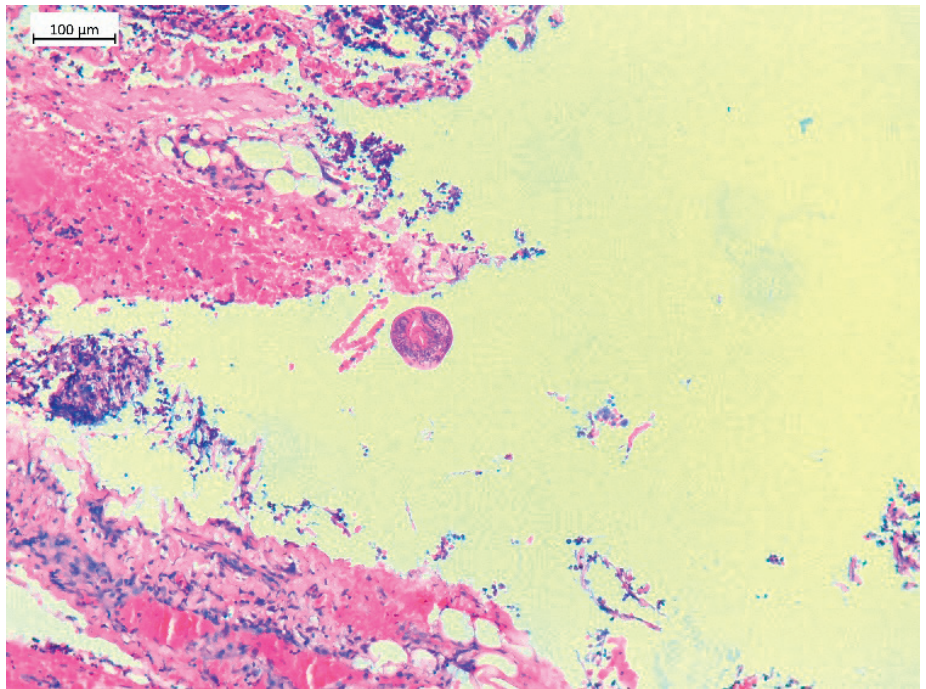

Figure 3.

Фигура 3.

There is no serological or molecular diagnosis of dirofilariasis in Bulgaria, i.e the diagnosis is only histological. As mentioned above, in this case conservative treatment is unjustified. We proceeded to an operative one, and our goal was to reject or prove a malignant process. A portion of the infiltrative growth tumor covering the lower pole of the left parotid gland was excised and sent for histological examination. The soft tissues of the neck had the appearance of phlegmonous inflammation. (Figure 4.)

During the dissection of levels II and III we came across a whitish exudate without odor, which was sent for microbiological examination. The microbiological test remained sterile. The histopathological one on the other hand, turned out to be diffuse large B-cell lymphoma.
В България липсва серологична или молекулярна диагностика на дирофилариозата, т.е. диагнозата е единствено хистологична. Както посочихме по-горе, в случая консервативното лечение е неоправдано. Пристьпихме към оперативно такова, като целта ни бе да отхвърлим или докажем малигнен процес. Ексцизира се част от туморна формация с инфилтративен растеж, обхващаща долния полюс на лява паротидна жлеза, и се изпрати за хистологично изследване. Меките тъкани на шията бяха с вид на флегмонозно възпаление (Фигура 4.), при дисекция на нива II и III се попадна на белезникав ексудат без миризма, който се изпрати за микробиологично изследване. Секретът остана стерилен. Полученият хистопатологичен логичен резултат бе дифузен едроклетъчен В-клетъчен лимфом.

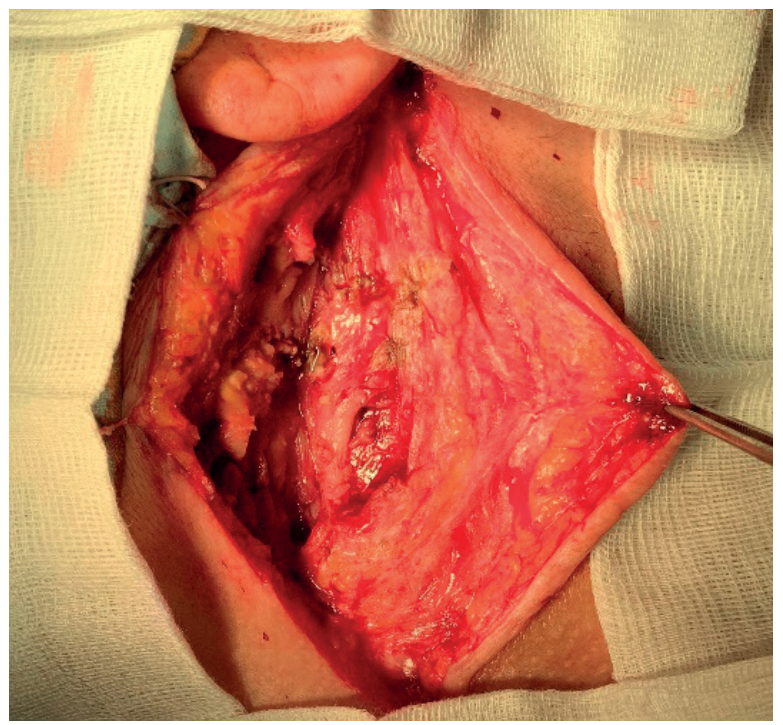

Figure 4.

Фигура 4. 


\section{Conclusion}

There are isolated cases of comorbidity between parasitic and oncological diseases in the literature. In some cases, the parasites are directly associated with carcinogenesis: Schistosoma haemotobium (bladder cancer), Schistosoma japonicum (colon cancer), Opistochostis (cholangiocarcinoma). In 2012 in Poland, a case of ocular dirofilariasis was described in a 61-year-old woman who was diagnosed with MALT lymphoma 9 months after removal of D. repens. In 2005 in the United States, accidental diagnosis of pulmonary dirofilariasis has been reported in a patient with lymphoma in remission. In 2017 in India in a 62-year-old man with a lymph node package on the left neck (level II) and sialoadenitis of the left submandibular gland, and a history of dirofilariasis 10 years back, was diagnosed with non-Hodgkin's lymphoma, which was treated conservatively with PCT.

In our case during the period of histological verification of tissue materials, the general condition of the patient deteriorated, hematemesis and melena appeared with subsequent hypovolemic shock and despite adequate therapeutic measures, exitus lethalis was registered.

\section{Заключение}

В литературата съществуват единични случаи на коморбидност между паразитни и онкологични заболявания. В някои случаи паразитите са директно асоциирани с карциногенеза: Schistosoma haemotobium (карцином на пикочен мехур), Schistosoma japonicum (карцином на дебелото черво), Opistochostis (холангиокарцином). През 2012г. в Полша е описан случай на окуларна дирофилариоза при 61-годишна жена, която е диагностицирана с МАЛТ лимфом 9 месеца след отстраняването на D. repens. През 2005г. в САЩ се съобщава за случайно диагностицирана белодробна дирофилариоза при пациент с доказан лимфом в ремисия. През 2017 г. в Индия при 62-годишен мъж с пакет лимфни възли на ниво II отляво на шията и сиалоаденит на лява субмандибуларна жлеза, и анамнестични данни за прекарана преди 10 г. дирофилариоза хистопатологично и имунохистохимично се доказва Неходжкинов лимфом, който се лекува консервативно с ПХТ.

В представения от нас случай в периода на извършване на хистологична верификация на тъканните материали общото състояние на пациентката се влоши, появи се хематемеза и мелена с последващ хиповолемичен шок и въпреки адекватните терапевтични мерки се регистрира екзитус леталис.

\section{Референции:}

1. Koltchko A., Wallance MR., Dirofilariasis: Practise essentials, Background, Pathopshysiology. Emedicine. http://emedicine.mdescape.com/ article/236698 Jan 2010

2. Петров П., Курдова Р. Дирофилариози. Клинична паразитология и тропическа медицина, 2016; 291-292

3. Дирофилариоза при хората в България - рядко, но съществуващо заболяване. Р. Харизанов, А. Иванова, И. Райнова, НЦЗПБ

4. Zweig A, Karasik A, Hiss J. Dirofilaria in a cervical lymph node in Israel. Hum Pathol. 1981 Oct;12(10):939-40. doi: 10.1016/s00468177(81)80201-8. PMID: 7298051.

5. To KK, Wong SS, Poon RW, et al. A novel Dirofilaria species causing human and canine infections in Hong Kong. Journal of Clinical Microbiology. 2012 Nov;50(11):3534-3541. DOI: 10.1128/jcm.01590-12.

6. Estran Ch., Marty P., Blanc V., et al. Human dirofilariasis: 3 cases in the south of France. La Presse Médicale 2007 May;36(5 Pt 1):799-803

7. Sarkari B, Lari M, Shafiei R, Sadjjadi S M. A Comparative Seroprevalence Study of Toxocariasis in Hypereosinophilic and Apparently Healthy Individuals, Arch Pediatr Infect Dis. 2015 ; 3(2):e17911. doi: 10.5812/pedinfect.17911.

8. PLOS. „Meta-analysis indicates that one-fifth of the world“s population exposed to Toxocara." ScienceDaily. ScienceDaily, 19 December 2019

9. Borkowski PK, Rymkiewicz G, Golebiewska J, et al. The first case of human autochtonous subconjunctival dirofilariosis in Poland and MALT lymphoma as possible consequence of this parasitosis. Infect Agent Cancer. 2015;10(1):1. Published 2015 Jan 7. doi:10.1186/1750-9378-10-1

10. Katikireddy K., Kuschner G., Pulmonary dirofilariasis presenting as multiple pulmonary nodules in a patient with history of a lymphoma. Chest Journal 2005 Oct; Vol.128; Issue 4

11. Ramadas AA, Jose R, Varma B, Chandy ML. Cervical lymphadenopathy: Unwinding the hidden truth. Dent Res J (Isfahan). 2017;14(1):7378. doi:10.4103/1735-3327.201136 